\title{
Occurrence of Toxoplasma gondii DNA in sheep naturally infected and slaughtered in abattoirs in Pernambuco, Brazil ${ }^{1}$
}

\begin{abstract}
Mauro J.G. Bezerra², Jefferson A.L.O. Cruz, Eugênio S. Kung ${ }^{3}$, José G. Silva ${ }^{3}$, André S. Santos $^{3}$, Érica P.B.X. Moraes ${ }^{3}$, José W. Pinheiro Junior and Rinaldo A. Mota ${ }^{3 *}$

ABSTRACT.- Bezerra M.J.G., Cruz J.A.L.O., Kung E.S., Silva J.G., Santos A.S., Moraes E.P.B.X., Pinheiro Junior J.W. \& Mota R.A. 2014. Occurrence of Toxoplasma gondii DNA in sheep naturally infected and slaughtered in abattoirs in Pernambuco, Brazil. Pesquisa Veterinária Brasileira 34(4):329-331. Laboratory of Infectious Contagious Diseases in Domestic Animals, Universidade Federal Rural de Pernambuco, Rua Dom Manoel de Medeiros s/n, Recife, PE 52171-900, Brazil. E-mail: rinaldo.mota@hotmail.com

The aim of the present study was to assess the occurrence of antibodies to Toxoplasma gondii and to detect genomic DNA of the parasite in the reproductive organs, fetuses and fetal membranes of sheep in slaughterhouses in the state of Pernambuco, Brazil. The Indirect Immunofluorescence technique (IFA) was used for screening. The Polymerase Chain Reaction (PCR) was used to detect DNA of T. gondii in the animals that were positive in the serology. In the serology, 13/50 samples were positive and genomic DNA of $T$. gondii was detected in one uterus, tube, ovary, placenta and fetus (heart, brain and umbilical cord) sample from a sheep that was positive in the serology. The present study provides evidence of the occurrence of T. gondii DNA in the organs of the reproductive system, placenta and fetus of a naturally infected sheep.
\end{abstract}

INDEX TERMS: Toxoplasmosis, Toxoplasma gondii, sheep, Polymerase Chain Reaction.

RESUMO.- [Ocorrência de DNA de Toxoplasma gondii em ovelhas naturalmente infectadas e abatidas em matadouros de Pernambuco.] Objetivou-se estudar a ocorrência de anticorpos contra Toxoplasma gondii e detectar o DNA genômico do parasito em órgãos reprodutivos, fetos e anexos fetais de ovelhas em matadouros no estado de Pernambuco, Brasil. Foram coletadas amostras de soro sanguíneo, útero, trompas e ovários, além de fetos e placentas. Para a triagem utilizou-se a técnica de Imunofluorescência Indireta (RIFI) e para a detecção do DNA de T. gondii empregou-se a Reação em Cadeia da Polimerase (PCR) nos animais positivos na sorologia e em todos os fetos e ane-

\footnotetext{
${ }^{1}$ Received on February 21, 2014.

Accepted for publication on March 30, 2014.

${ }^{2}$ Postgraduate student in Tropical Animal Science, Universidade Federal Rural de Pernambuco (UFRPE), Campus de Dois Irmãos, Rua Dom Manoel de Medeiros s/n, Dois Irmãos, Recife, PE 52171-900. Veterinarian at Superintendência de Desenvolvimento do Nordeste (SUDENE), Praça Ministro João Gonçalves de Sousa s/n, Engenho do Meio, Recife, PE 50670-900, Brazil.

${ }^{3}$ Laboratório de Doenças Infecto-Contagiosas de Animais Domésticos, UFRPE, Rua Dom Manoel de Medeiros s;n, Recife, PE 52171-900. *Autor para correspondência: rinaldo.mota@hotmail.com

${ }^{4}$ Unidade Acadêmica de Garanhuns, UFRPE, Av. Bom Pastor s/n, Boa Vista, Garanhuns, PE 55292-270, Brazil.
}

xos fetais. Na sorologia, 13/50 amostras foram positivas e o DNA genômico de T. gondii foi detectado em uma amostra de útero, trompa, ovário, placenta e feto (coração, cérebro e cordão umbilical) de uma ovelha positiva na sorologia. A identidade molecular dos produtos amplificados foi confirmada por sequenciamento. Neste estudo comprova-se a ocorrência do DNA de T. gondii em órgãos do sistema reprodutivo, placenta e feto de ovelha naturalmente infectada.

TERMOS DE INDEXAÇÃO: Toxoplasmose, Toxoplasma gondii, ovelha, Reação em Cadeia da Polimerase.

\section{INTRODUCTION}

Toxoplasmosis is a significant zoonosis with a worldwide distribution and is considered to be one of the main causes of reproductive disorders in sheep worldwide (Dubey \& Schmitz 1981, Dubey 1986, 1988, Dubey et al. 1986, Underwood \& Rook 1992).

Barberan \& Marco (1997) studied the reproductive aspects of ovine toxoplasmosis and reported the following possible results: embryo resorption; abortion; malformed fetuses and weak, debilitated offspring. Sheep are usually infected by ingesting oocysts with food and water, although congenital transmission is also considered to be significant 
in this species (Blewett et al. 1982, Duncanson et al. 2001, Williams et al. 2005, Buxton et al. 2006).

In Denmark, Thamsborg et al. (1994) reported abortions related to toxoplasmosis in naturally infected sheep using techniques of histopathology and bioassays with mice. In Spain, Pereira \& Bueno (2004) also demonstrated the presence of Toxoplasma gondii DNA in aborted fetuses from naturally infected sheep. Masala et al. (2007) detected T. gondii DNA in the tissues of aborted fetuses in Italy. In Brazil, Moraes et al. (2011) found T. gondii in aborted and stillborn sheep fetuses in nested PCR, thereby demonstrating the significance of this disease in sheep reproduction.

Among naturally infected animals, there are no records of the occurrence of this parasite in the reproductive organs, fetuses or embryos of sheep that were slaughtered for consumption. Since the distribution of T. gondii in tissues from slaughtered animals has already been studied extensively in farm animals, the present study aimed to investigate the presence of this parasite in organs that have not yet been studied, associated with reproductive aspects. The sexual transmission of this parasite was recently proven in association with the experimental infection of sheep (Moraes et al. 2010a, 2010b). This result inspired the performance of the present study, which aimed to detect genomic DNA of $T$. gondii in the uterus, tubes, ovaries, fetuses and placenta of sheep that were serologically positive and slaughtered in slaughterhouses in the state of Pernambuco, Brazil.

\section{MATERIALS AND METHODS}

Blood serum samples, organs of the reproductive system, fetus and placenta. Fifty blood serum samples, 50 uterus, tube and ovary samples, 15 fetuses and 15 placentas were collected from sheep of different breeds in slaughterhouses in the state of Pernambuco, Brazil.

Serology. Indirect Immunofluorescence (IFA) was used to detect IgG antibodies to T. Gondii, as described by Camargo (1964): anti-sheep IgG $\left(\right.$ Sigma $\left.^{\circledR}\right)$; conjugated to fluorescein isothiocynate; a cut-off point of 64; using tachyzoites of the RH strain as an antigen; previously known positive and negative control reactions were included in all groups.

Molecular examination to detect Toxoplama gondii DNA. Tissue samples from the sheep that were positive in the serology were sent for a molecular examination. Tissue samples from the females (uterus, tubes and ovaries) and the fetuses (brain, heart, placenta and umbilical cord) were used for DNA extraction. The DNA was extracted using the Wizard Genomic DNA Purification (Promega ${ }^{\circledR}$ ) commercial kit, following the manufacturer's instructions.

The primer pairs used in the PCR were TOX4 (CGCTGCAGGGAGGAAGACGAAAGTTG) and TOX5 (CGCTGCAGACACAGTGCATCTGGATT), as described by Homan et al. (2000), amplifying a region of 529 base pairs (bp). The amplification reactions were conducted at a final volume of $12.5 \mu \mathrm{L}$ containing: $2.5 \mu \mathrm{L}$ of genomic DNA; $0.5 \mu \mathrm{L}$ of each primer (TOX4 and TOX5) at $10 \mu \mathrm{M} ; 2.5 \mu \mathrm{L}$ of ultra-pure Milli-Q water and 6.25 $\mu \mathrm{L}$ of Top Taq Master Mix (Qiagen ${ }^{\circledR}$ ), following the manufacturer's instructions. The thermal profile of the stages of the reaction was conducted in an XP Thermal Cycler (Bioxer Technology CO. LTDA). This process consisted of an initial DNA denaturation at $94^{\circ} \mathrm{C}$ ( 7 minutes), followed by 35 cycles at $94^{\circ} \mathrm{C}$ for 1 minute for denaturation, $60^{\circ} \mathrm{C}$ for 1 minute for annealing, $72^{\circ} \mathrm{C}$ for 1 minute for extension and a final extension of 10 minutes at $72^{\circ} \mathrm{C}$. The products amplified were detected by electrophoresis in agarose gel $2 \%$, stained with Blue Green (LGC ${ }^{\circledR}$ ), visualized in ultraviolet light and photodocumented. The positive control used in the reaction was obtained by suspending the washed intraperitoneal of mice that were previously infected with the RH strain.

For the sequencing, the products amplified were purified using commercial GFXTM PCR DNA and a Gel Band Purification kit (GE Healthcare). Using the sequencer ABI PRISM 3100 (Applied Biosystems), reactions were carried out in both strands using the primers (TOX4 and TOX5), according to the Big Dye Terminator v3.1 Cycle Sequencing Kit (Applied Biosystems ${ }^{\circledR}$ ). The polymerization was performed in 96-well plates, following the manufacturer's instructions. Sequences were analyzed through Bioedit and MEGA 5 software and compared with the NCBI database using Blast.

\section{RESULTS}

In the serology, 13/50 samples tested were positive. Of the 50 sheep studied, 09 were pregnant and 05 were positive in the IFA.

In the PCR, one pregnant sheep was positive for Toxoplasma gondii (uterus, tubes and ovaries). The placenta and fetus were also positive (heart and brain). The other $14 \mathrm{fe}-$ tuses and placentas were negative.

The molecular identity was confirmed through direct double-stranded sequencing which indicated 99.9\% similarity with the DNA sequences of T. gondii stored in the Genbank (DQ779196.1).

\section{DISCUSSION}

In the present study, the frequency of $26 \%$ of positive sheep obtained in the IFA is close to the results obtained by Silva et al. (2003) in the same region: $35.3 \%$ of seropositive sheep. Other studies in several regions of Brazil have recorded values ranging from $7 \%$ to $55 \%$, which may reflect the different temperatures and humidity levels of the regions studied, as well as the age of the animals, the breeding system, the serological test and the cut-off point used. Serological studies in several countries worldwide have investigated the prevalence of antibodies to T. gondii in sheep, and the results range from 3\% to 92\% (Dubey 1990, 2009).

The positive sheep found in the present study was destined for consumption by the local population, which is worrying from a public health point of view, since muscles with viable cysts could be a source of infection among humans. In the present study, the parasite was not investigated in the organs of choice for the formation of cysts. There have already been numerous studies of the significance of human consumption of muscles and viscera contaminated with Toxoplasma gondii. However, no previous studies have investigated toxoplasmosis in humans in this region of Brazil, associated with the consumption of the meat and viscera of ruminants. The results of the present study could serve to stimulate other epidemiological studies in this area.

With regards to the implications for the health of the animals, particularly in terms of sheep reproduction, Duncanson et al. (2001) reported congenital transmission of T. gondii among sheep, with $94 \%$ of lambs positive and aborted in Australia. The authors also found the parasite in placental tissue of successful pregnancies. They suggested that congenital transmission occurred in a high percentage 
of the lambs that were born alive, and that the transplacental transmission route could explain the persistence of the parasite in herds, without the need for new infections through oocysts excreted by cats.

In Brazil, abortion as a result of T. gondii has previously been reported in a number of regions. However, a study of the presence of this parasite in the reproductive organs of slaughtered sheep has not yet been conducted. The presence of T. gondii DNA in the placenta, heart and brain of the fetus of a sheep that was positive in the serology confirmed the vertical transmission of the parasite in naturally infected sheep in Brazil. The following data, related to spontaneous abortions caused by T. gondii, are recorded in the literature: $10.6 \%$ in Germany (Steuber et al. 1995); 11.1\% and $18.1 \%$ in Italy (Masala et al. 2003, 2007); 14.3\% in Brazil (Moraes et al. 2011); $16.9 \%$ and $23.2 \%$ in Spain (Hurtado et al. 2001, Pereira-Bueno et al. 2004) and $17.5 \%$ in the USA (Dubey \& Kirkbride 1990).

The sheep that was positive in the serology was also positive in the PCR of the uterus, ovaries and tubes. These findings are significant in the epidemiology of ovine toxoplasmosis since they have not been seen before in cases of natural infection. However, it is too early to discuss with any certainty the meaning of the presence of this parasite in the reproductive organs of naturally infected sheep. In cases of congenital transmission, it is known that the parasite arrives in the placenta and fetus through the blood. However, Rodriguez et al. (2013) recently inoculated lambs with T. gondii and confirmed the infection of females through natural mating, finding the parasite in the sheep and their lambs using PCR. These results demonstrated the sexual transmission of T. gondii among sheep with a consequent vertical transm000ission to the offspring. Moraes et al. (2010a and 2010b) confirmed venereal transmission of the parasite during insemination with semen that had been experimentally infected with T. gondii and reported reproductive disorders including fetal death, abortion, hydrometra, mucometra, follicular cysts, anestrous and high rates of embryo resorption.

It was not possible in the present study to detect the phase of infection or the transmission route of the parasite. Despite the fact that the life cycle of T. gondii is well known, the presence of genomic DNA of the parasite in samples of the reproductive system of naturally infected sheep demonstrates that certain aspects of this infection require further investigation.

This is the first report of the occurrence of T. gondii DNA in samples of uterus, tubes and ovaries from naturally infected sheep that were slaughtered in Pernambuco, Brazil.

\section{REFERENCES}

Barberan M. \& Marco J.C. 1997. Patogenia, cuadro clinico y lesional-Toxoplasmosis. Ovis 52:35-49.

Blewett D.A., Teale A.J., Miller J.K., Scott G.R. \& Buxton D. 1982. Toxoplasmosis in rams: possible significance of venereal transmission. Vet. Rec. 24:73-75.

Buxton D., Rodger S.M., Maley S.W. \& Wright S.E. 2006. Toxoplasmosis: the possibility of vertical transmission. Small Rumin. Res. 62:43-46.

Camargo M.E. 1964. Introdução às técnicas de imunofluorescência. Revta Bras. Patol. Clin. 10:43-71.
Dubey J.P. \& Schmitz J.A. 1981. Abortion associated with Toxoplasmosis in sheep in Oregon. J. Am. Vet. Med. Assoc. 178:675-678.

Dubey J.P. 1986. A review of toxoplasmosis in cattle. Vet. Parasitol. 22:177202.

Dubey J.P., Milles S., Powell C.C. \& Anderson W.R. 1986. Epizootioloic investigations on a sheep farm with Toxoplasma gondii induced abortions. J. Am. Vet. Med. Assoc. 188:155.

Dubey J.P. 1988. Lesions in transplacentally induced toxoplasmosis in goats. Am. J. Vet. Res. 49:905-909.

Dubey J.P. 1990. Status of toxoplasmosis in sheep and goats en the United Station. J. Am. Vet. Med. Assoc. 196:259-262.

Dubey J.P. \& Kirkbride C.A. 1990. Toxoplasmosis and other causes of abortions in sheep from the north central United States. J. Am. Vet. Med. Assoc. 196:287-290.

Dubey J.P. 2009. Toxoplasmosis in sheep: the last 20 years. Vet. Parasitol. 163:1-14.

Duncanson P., Terry R.S., Smith J.E. \& Hide G. 2001. High levels of congenital transmission of Toxoplasma gondii in a commercial sheep flock. Int. J. Parasitol. 31:699-1703.

Homan W.L., Vercammen M., De Braekeleer J. \& Verschueren H. 2000. Identification of a 200- to 300 - fold repetitive 529 bp DNA fragment in Toxoplasma gondii, and its use for diagnostic and quantitative PCR. Int. J. Parasitol. 30:69-75.

Hurtado A., Aduriz G., Moreno B., Barandika J. \& García-Pérez A.L. 2001. Single tube nested PCR for the detection of Toxoplasma gondii in fetal tissues from naturally aborted ewes. Vet. Parasitol. 102:17-27.

Masala G., Porcu R., Madau L., Tanda A., Ibba B., Satta G. \& Tola S. 2003. Survey of ovine and caprine toxoplasmosis by IFAT and PCR assays in Sardinia, Italy. Vet. Parasitol. 117:15-21.

Masala G., Porcu R., Daga C., Denti S., Canu G., Patta C. \& Tola S. 2007. Detection of pathogens in ovine and caprine abortion samples from Sardinia, Italy, by PCR. J. Vet. Diagn. Invest. 19:96-98.

Moraes E.P.B.X., Batista A.M., Faria E.B., Freire R.L., Freitas A.C., Silva M.A.R., Braga V.A. \& Mota R.A. 2010a. Experimental infection by Toxoplasma gondii using contaminated semen containing different doses of tachyzoites in sheep. Vet. Parasitol. 170:318-322.

Moraes E.P.B.X., Freitas A.C., Gomes-Filho M.A., Guerra M.M.P., Silva M.A.R., Pereira M.F., Braga V.A. \& Mota R.A. 2010b. Characterization of reproductive disorders in ewes given anintrauterine dose of Toxoplasma gondii tachyzoites during the intrauterine insemination. Anim. Reprod. Sci. 122:36-41.

Moraes E.P.B.X., Costa M.M., Dantas A.F.M., Silva J.C.R. \& Mota R.A. 2011. Toxoplasma gondii diagnosis in ovine aborted fetuses and stillborns in the State of Pernambuco, Brazil. Vet. Parasitol. 183:152-155.

Pereira-Bueno J., Quintanilla-Gozalo A., Perez-Perez V., Alvarez-Garcia G., Collantes-Fernandez E. \& Ortega-Mora L.M. 2004. Evaluation of ovine abortion associated with Toxoplasma gondii in Spain by different diagnostic techniques. Vet. Parasitol. 121:33-43.

Rodrigues J.D., Souza F.A., Santos T.R., Santos R.S., Rosanese W.M., Lopes W.R.Z., Sakamoto C.A. \& Costa A.J. 2013. Sexual transmission of Toxoplasma gondii in sheep. Vet. Parasitol. 195:47-56.

Silva A.V., Cunha E.L.P., Meireles L.R., Gottscchalk S., Mota R.A. \& Langoni H. 2003. Toxoplasmose em ovinos e caprinos: estudo soroepidemiológico em duas regiões no Estado de Pernambuco, Brasil. Ciência Rural 33:115-119.

Steuber S., Niu A., Bauer C., Reetz J., Roth A. \& Janitschke K. 1995. Der Nachweis von Toxoplasma gondii in Abortgeweben vom Schaf mittels der Polymerase-Kettenreaktion. Dtsch. Tierärztl. Wochenschr. 102:91-93.

Thamsborg S.M., Ilsoe B., Henriksen S.A. \& Lind P. 1994. Toxoplasma-abort hos far. Dansk Veterinaertidsskrift 77:925-930.

Underwood W.J. \& Rook J.S. 1992. Toxoplasmosis infection in sheep. Compend. Contin. Educ. Pract. Vet. 14:1543-1549.

Williams R.H., Morley E.K., Hughes J.M., Duncanson P., Terry R.S., Smith J.E. \& Hide G. 2005. High levels of congenital transmission of Toxoplasma gondii in longitudinal and crosssectional studies on sheep farms provides evidence of vertical transmission in ovine hosts. Parasitol. 130:301-307. 